\title{
WSPÓLNE DECYZJE CENOWE JAKO NARZĘDZIE TWORZENIA I UMACNIANIA PARTNERSTWA TURYSTYCZNEGO PRZYKŁAD POZNANIA
}

\author{
Zarządzanie turystyką $w$ teorii i praktyce \\ w latach 1989-2009
}

$\mathrm{W}$ dyskusji na temat przemian $\mathrm{w}$ polskiej turystyce $\mathrm{w}$ ostatnich 20 latach warto poświęcić uwagę ewolucji teorii i praktyki szeroko pojętego zarządzania turystyką. W pierwszych latach po transformacji ustrojowej, w nowych warunkach gospodarki rynkowej i prymacie własności prywatnej podstawowym problemem odradzającej się turystyki było osiąganie skuteczności i efektywności działania $\mathrm{w}$ skali mikroekonomicznej $\mathrm{w}$ odniesieniu do przedsiębiorstw. Następnie zwrócono uwagę na rolę administracji państwowej i samorządowej w tworzeniu warunków rozwoju turystyki w regionach.

Obecnie polska turystyka staje przed kolejnym wyzwaniem rozwojowym mającym zasięg globalny. Jest nim proces upodmiotowienia regionów i miejscowości na rynku turystycznym. Konieczne staje się przeniesienie zarządzania turystyką na szczebel mezoekonomiczny (czyli lokalny i regionalny), przejęcie filozofii bezpośredniego zaangażowania w konkurencyjną walkę o turystę przez miasta i regiony w oparciu o silne struktury partnerskie. 
Zjawisko to związane jest $\mathrm{z}$ rosnącą rolą organizacji zwanych ogólnie Destination Management Organisations (DMO - Lokalna/Regionalna Organizacja Turystyczna) funkcjonujących jako podmioty koordynujące przepływ wiedzy i informacji, tworzące wizerunek obszarów recepcji turystycznych oraz kreujące terytorialne produkty turystyczne (KRUCZEK, ZMYŚLONY 2010). W 2005 roku Fundacja Światowej Turystyki (World Tourism Foundation) zapowiedziała, że „do roku 2012 DMO staną się dominująca, najbardziej wpływową i szanowaną siłą największego przemysłu świata lub... nie będą wcale istnieć" (MINTEL 2005, s. 1). Z dzisiejszej perspektywy pierwszy scenariusz jest jak najbardziej prawdopodobny, może jednak w nieco dłuższym okresie. Niewątpliwie aktywność DMO będzie wyznaczać kierunki rozwoju turystyki w najbliższych latach.

Rosnąca globalna konkurencja na szczeblu miast i regionów turystycznych sprawia, że stosowane na tym rynku narzędzia i techniki marketingowe stają się coraz bardziej wyrafinowane, wymykają się podstawowym zakresom standardowego marketingu-mix i zacierają granice między nimi (FLOREK 2007, s. 178). Niezależnie jednak od zastosowanego instrumentu, skuteczność działań zależy niezmiennie od współpracy między podmiotami zaangażowanymi w rozwój turystyki. Gwarantem powodzenia jest budowa trwałej struktury partnerskiej.

Tezą opracowania jest stwierdzenie, że wspólne decyzje cenowe w formie jednoczesnej obniżki cen wielu usług turystycznych mogą być wykorzystane jako specyficzny test potencjału partnerskiego w regionie, niezależnie od tego, czy jest ono tworzone tylko w celu przeprowadzenia tego działania, czy jest budowane dla szerszych i długookresowych celów strategicznych. Celem autora niniejszej pracy jest zbadanie możliwości wykorzystania wspólnych obniżek cen nie tylko (a nawet nie tyle) jako instrumentu terytorialnego marketingu-mix, ale jako narzędzia budowania i weryfikacji potencjału partnerskiego tkwiącego w lokalnej gospodarce turystycznej. Rozważania zostaną oparte na przykładzie trzech edycji akcji „Poznań za pół ceny!" przeprowadzanej corocznie w Poznaniu od 2008 r. Podczas badań zastosowano wtórne i pierwotne źródła badawcze $\mathrm{z}$ wykorzystaniem następujących metod i technik: analizy dokumentów, obserwacji uczestniczącej wynikającej z zaangażowania autora $\mathrm{w}$ przebieg akcji, wywiadu bezpośredniego niestandaryzowanego (z koordynatorem wydarzenia) oraz ankiety skierowanej do podmiotów biorących udział w akcji (w 2008 r. wykorzystano ankietę tradycyjna, w latach 2009 i 2010 ankietę internetową) (OLSZEWSKI, ZMYŚLONY 2008, 2009, SZMATUŁA, ZMYŚLONY 2010). Prezentowane rezultaty poznawcze oparte są na wynikach zebranych ze wszystkich stosowanych metod łącznie. 
WSPÓLNE DECYZJE CENOWE JAKO NARZĘDZIE TWORZENIA PARTNERSTWA TURYSTYCZNEGO...

\section{Obniżki cenowe jako instrument turystycznego marketingu terytorialnego}

W praktyce terytorialnego marketingu turystycznego wykorzystywanie instrumentów związanych z ceną jest rzadkie. BUHALIS (2000, s. 110) stwierdza, że określanie cen dla niezwykle złożonego produktu danego terytorium jest skomplikowanym procesem, a lokalna organizacja turystyczna może jedynie pośrednio kontrolować wybrane jego elementy poprzez regulacje, doradztwo i współpracę z sektorem prywatnym, przy czym często przyjmuje to formę określania cen minimalnych dla niektórych usług $w$ celu ochrony małych lokalnych przedsiębiorców (np. usług noclegowych) lub cen maksymalnych chroniących interesy nabywców (np. usługi transportowe). Stosowanie cen promocyjnych jest narzędziem usytuowanym na styku działań z zakresu promocji (promocja sprzedaży), ceny (ceny promocyjne) oraz public relations (wydarzenie marketingowe). KOLB (2006, s. 261) wyróżnia dwie formy obniżek cen $\mathrm{w}$ ramach turystycznej promocji sprzedaży stosowane $\mathrm{w}$ miastach: rabaty posezonowe oraz pakietyzacja usług turystycznych z wydarzeniami kulturalnymi. Stosowanie zachęt cenowych zamienia się często $\mathrm{w}$ wydarzenie wspomagane kampanią promocyjna, dzięki której akcja oraz, co ważniejsze, miejscowość i region uzyskują medialny rozgłos. Podkreślana już rzadkość stosowania tego narzędzia marketingowego wynika z następujących uwarunkowań:

- urządzenia i usługi będące elementami terytorialnego produktu turystycznego są jednocześnie oferowane i konsumowane przez wiele grup odbiorców, trudno zatem jest wyróżnić te usługi i produkty, których cena powinna być obniżona, a także segmenty odbiorców tych obniżek;

- terytorialny produkt turystyczny jest wytwarzany przez wiele podmiotów oferujących swe produkty na różnych rynkach mających różne cele działania oraz realizujących własne strategie marketingowe (BUHALIS 2000), w związku z czym promocyjne ceny mogą być w indywidualnych przypadkach niemożliwe do zastosowania lub wchodzić $\mathrm{w}$ konflikt $\mathrm{z}$ innymi stosowanymi indywidualnie technikami i narzędziami marketingowymi;

- według ASHWORTHA i VOOGDA (1994), zbiór użyteczności danego terytorium jest częściowo udostępniany w sposób pośredni, niematerialny, co zazwyczaj nie jest wyrażone w jednostkach pieniężnych. Wiele istotnych atrakcji i urządzeń nosi cechy dóbr publicznych lub klubowych (SAMUELSON, NORDHAUS 1995), jest zatem udostępniana 
turystom na zasadach pozarynkowych, w cenach regulowanych lub za darmo (SOCHER 2006), wobec czego taktyczne zmiany cen ich nie dotycza;

- z uwagi na zaangażowanie różnorodnych rodzajów działalności w promocji sprzedaży problemem może okazać się ustalenie czytelnych i w miarę prostych zasad obniżania cen.

Pomimo wymienionych trudności stosowanie zachęt cenowych w marketingu terytorialnym może przynieść pozytywne efekty. Po pierwsze, atrakcyjne ceny dóbr i usług turystycznych są kluczowym elementem determinującym zadowolenie odwiedzających z dokonanej wizyty turystycznej. KOTLER, HAIDER i REIN (1993, s. 212) wskazują że "turyści porównują koszty z korzyściami uzyskanymi z pobytu $\mathrm{w}$ danym miejscu, zatem oczekują że zainwestowane czas, wysiłek i inne zasoby zwrócą się im $\mathrm{w}$ formie nabytej wiedzy, doświadczenia, zabawy, relaksu i przyszłych wspomnień z podróży". Dla wybranych segmentów rynku (np. studentów) cena może być nawet najważniejszym czynnikiem oceny wizerunku miejscowości lub regionu (PIKKEMAAT 2004).

Po drugie, wydarzenie $\mathrm{w}$ formie promocji sprzedaży może przynieść pozytywny efekt $\mathrm{w}$ procesie tworzenia atrakcyjnego wizerunku miejscowości i regionu oraz budowania relacji z odbiorcami produktu turystycznego. Dotyczy to szczególnie miejsc, które nie mają ugruntowanej pozycji na rynku turystycznym bądź wprowadzają strategię zmiany wizerunku lub repozycjonowania swojej pozycji rynkowej. W tym wypadku podkreśla się rolę komunikacyjną tego narzędzia - sprawnie przeprowadzone wydarzenie nie tylko zwiększa liczbę odwiedzających dany obszar w czasie jego trwania, ale także przyciąga uwagę szerszej publiczności, dostarcza pożądaną informację, która może kreować pozytywne postawy wobec danej miejscowości lub regionu.

\section{Uwarunkowania partnerstwa turystycznego}

W regionach turystycznych potrzeba współdziałania wynika wprost z konieczności tworzenia i oferowania na rynku spójnych terytorialnych produktów turystycznych, zderzonej z fragmentaryzacją i wzajemną zależnością podmiotów podaży turystycznej. Według WOOD i GRAY (1991, s. 146), „współpraca powstaje, kiedy grupa suwerennych podmiotów zaangażowanych w daną dziedzinę działalności angażuje się, w ramach uzgodnionych 
regut, norm i stopnia organizacji struktur we wspólny proces podejmowania działań lub decyzji związanych z tą dziedziną". Według BRAMWELLA i LANE'A (2000, s. 5), struktury partnerskie mogą być zawiązywane zarówno dla realizacji ogólnych celów strategicznych, jak i ściśle określonych kwestii $\mathrm{w}$ ramach pojedynczego projektu. W pracach na ten temat podkreśla się jednak częściej kontekst strategiczny, szczególnie w odniesieniu do zarządzania strategicznego, długookresowych strategii marketingowych czy polityki turystycznej (BUHALIS 2000, FYALL, GARROD 2005, MURPHY, MURPHY 2004, RITCHIE, CROUCH 2003).

Należy mocno podkreślić, że partnerstwo to proces, którego skuteczność należy weryfikować nie tylko przez pryzmat wspólnych prac koncepcyjnych, uzgodnień oraz decyzji, ale także - lub nawet przede wszystkim w czynnej realizacji wspólnych idei i pomysłów. Ważne jest, aby określenie „podejmowanie decyzji lub działań” użyte w definicji WOOD i GRAY (1991) było rozumiane nie jako alternatywa, ale dopełniające się obszary aktywności partnerów. W praktyce powinno zatem oznaczać "podejmowanie decyzji i działań" tak często, jak to możliwe. Niestety, w wielu przypadkach zdolność podmiotów do współdziałania okazuje się mała - partnerstwo ograniczane jest do podejmowania decyzji, zatem wiele inicjatyw partnerskich kończy swój cykl życia tylko na papierze, nie przechodząc do praktycznych działań. CAFFYN (2000, s. 202) podkreśla, że „struktury, które mają trudności $\mathrm{z}$ procesem współpracy pogrążają się $\mathrm{w}$ inercji i frustracji prowadzących do stanu «wyczerpania współpracą» i prawdopodobnie zakończeniem partnerstwa".

W większości regionów struktury partnerskie są zawiązywane zwykle po raz pierwszy, a doświadczenie na tym polu nie przychodzi szybko, zatem $\mathrm{w}$ pewnym sensie wszyscy partnerzy są amatorami $\mathrm{w}$ tym procesie. $\mathrm{Z}$ tego względu niezmiernie ważne jest, aby można było przetestować partnerów $\mathrm{w}$ realizacji pojedynczych, taktycznych działań, zanim przyjdzie czas na planowanie i implementację długookresowych i wielkoskalowych projektów mających na celu wywołanie znacznych zmian w gospodarce turystycznej. Może się bowiem zdarzyć, że sami partnerzy przeceniają swoje możliwości współdziałania, co może doprowadzić do szybkiego załamania partnerstwa. W tym kontekście taka „próba generalna” powinna być traktowana jako weryfikacja zdolności utrzymania partnerstwa, kluczowa dla przesunięcia współpracy z fazy startu do fazy wzrostu według modelu cyklu życia partnerstwa zaproponowanego przez CAFFYN (2000). 


\section{Wspólne decyzje cenowe jako test potencjału partnerskiego: prezentacja wyników badań}

Akcja „Poznań za pół ceny” przeprowadzana jest w stolicy Wielkopolski od 2008 r. Pomimo to, że główne wskaźniki wielkości ruchu turystycznego nie są niskie (w 2009 r. zarejestrowano 496 tys. turystów, 892 tys. osobonoclegów, 8000 miejsc noclegowych (Instytut Turystyki 2010), wizerunek miasta określa jego biznesowy profil zbudowany na bazie licznych imprez targowych i konferencji, dlatego potencjalni goście postrzegają miasto jako drogie i relatywnie nudne (IMAS 2006).

Uwarunkowania te legły u podstaw organizacji akcji „Poznań za pół ceny". Jej główna idea polega na wspólnym, jednoczesnym obniżeniu cen usług oferowanych turystom i mieszkańcom Poznania o 50\% przez podmioty ze sfery turystyki i kultury działające w mieście. Działania te mają wywołać wrażenie promocji sprzedaży całego produktu turystycznego miasta, zarówno wśród docelowych odbiorców, jak i w opinii publicznej. W ten sposób powstaje efekt synergii wynikający ze współdziałania różnorodnych rodzajów podmiotów reprezentujących sektor publiczny i sektor prywatny w ramach jednego celu. Akcja trwa dwa dni weekendowe następujące bezpośrednio po święcie Bożego Ciała będącym dniem wolnym od pracy. Do bezpośrednich celów akcji należy: zwiększenie popytu turystycznego w mieście; tworzenie wizerunku Poznania jako docelowego miejsca podróży weekendowych (tzw. city breaks), a przez to zwiększenie ruchu turystycznego $\mathrm{w}$ weekendy; uatrakcyjnienie wizerunku turystycznego miasta wśród turystów "kulturowych” i korzystających z krótkich wyjazdów weekendowych typu city breaks; zachęcenie podmiotów kulturowych i turystycznych do zwiększania aktywności marketingowej i uelastyczniania swoich ofert (OLSZEWSKI, ZMYŚLONY 2008). Oprócz wymienionych celów, równie istotne, mające charakter wewnętrzny, jest zwiększenie potencjału partnerskiego tkwiącego w lokalnej gospodarce turystycznej zarówno w sensie ilościowym, jak i jakościowym.

Prace organizacyjne rozpoczynają się na pół roku przed wydarzeniem i polegają na pozyskaniu partnerów medialnych i strategicznych, ustaleniu reguł wspólnych obniżek oraz wykreowaniu działań i imprez towarzyszących akcji. Zadania te wykonuje koordynator imprezy - Poznańska Lokalna Organizacja Turystyczna, funkcjonująca jako lokalna DMO - przy wsparciu finansowym Urzędu Miasta. Największym wyzwaniem w tym zakresie jest odpowiednio wczesna aktywizacja potencjalnych partnerów tak, by możliwe było przygotowanie na czas pełnej informacji promocyjnej na temat oferty 
wszystkich podmiotów. Zaproszenie do wspólnych działań PLOT kieruje nie tylko do swoich członków, ale także do innych podmiotów funkcjonujących na poznańskim rynku turystycznym. Obowiązkiem podmiotów przystępujących do akcji jest zaadaptowanie prostych reguł obniżki cen do swoich, często skomplikowanych, taktycznych schematów cenowych, a także wsparcie promocyjne za pośrednictwem własnych kanałów informacyjnych. Partycypacja w akcji nie wiąże się z pobieraniem dodatkowych opłat przez PLOT.

Rozpatrując wykorzystanie wspólnych zachęt cenowych jako weryfikacji potencjału partnerskiego należy rozróżnić dwa aspekty: bieżący stan i jakość współpracy oraz zdolność do poprawy partnerstwa w ramach przyszłych działań. Oba elementy mogą być ocenione na podstawie liczby współpracujących podmiotów w stosunku do podmiotów, które nie wyraziły akcesu, a także na podstawie ocen jakości wspólnych działań i opinii na temat możliwości poprawy współpracy oraz w kolejnych latach. Ponadto podczas trzeciej edycji akcji postanowiono dokładniej zbadać, czy wspólne działania cenowe przekładają się bezpośrednio na rozwój struktury partnerskiej w poznańskiej branży turystycznej i zapytano podmioty o plany wstąpienia do PLOT.

Tabela 1. Charakterystyka akcji „Poznań za pół ceny” w latach 2008-2010

\begin{tabular}{|l|c|c|c|}
\hline \multirow{2}{*}{ Wyszczególnienie } & \multicolumn{3}{|c|}{ Rok } \\
\cline { 2 - 4 } & 2008 & 2009 & 2010 \\
\hline Liczba odbiorców akcji & $\begin{array}{c}13000 \text { potencjalnych } \\
\text { odbiorców }\end{array}$ & $\begin{array}{c}21177 \\
\text { osobousług }\end{array}$ & $\begin{array}{c}65083 \\
\text { osobousług }\end{array}$ \\
\hline Podmioty uczestniczące w akcji & 35 & 58 & 113 \\
\hline Wypełnione ankiety & 21 & 55 & 88 \\
\hline Wskaźnik odpowiedzi (w \%) & 60 & 95 & 78 \\
\hline
\end{tabular}

Źródło: opracowanie własne na podstawie: OLSZEWSKI, ZMYŚLONY (2008), SZMATUŁA, ZMYŚLONY (2010).

W trakcie przygotowań do dwóch pierwszych edycji akcji PLOT zwróciła się do około 200 podmiotów różnych typów świadczących usługi turystom w Poznaniu (hoteli, restauracji, obiektów kultury, atrakcji turystycznych i innych) z propozycją współtworzenia promocji sprzedaży produktu turystycznego miasta. Przed trzecią edycją bazowano tylko na kontaktach podjętych w poprzednich latach oraz rozgłosie zdobytym w Polsce. Porównując tę liczbę $z$ danymi dotyczącymi liczby podmiotów uczestniczących w akcji (tab. 1) wynika, że o ile w pierwszym roku przekonanie partnerów do partycypacji w projekcie było największym wyzwaniem, to w kolejnych 


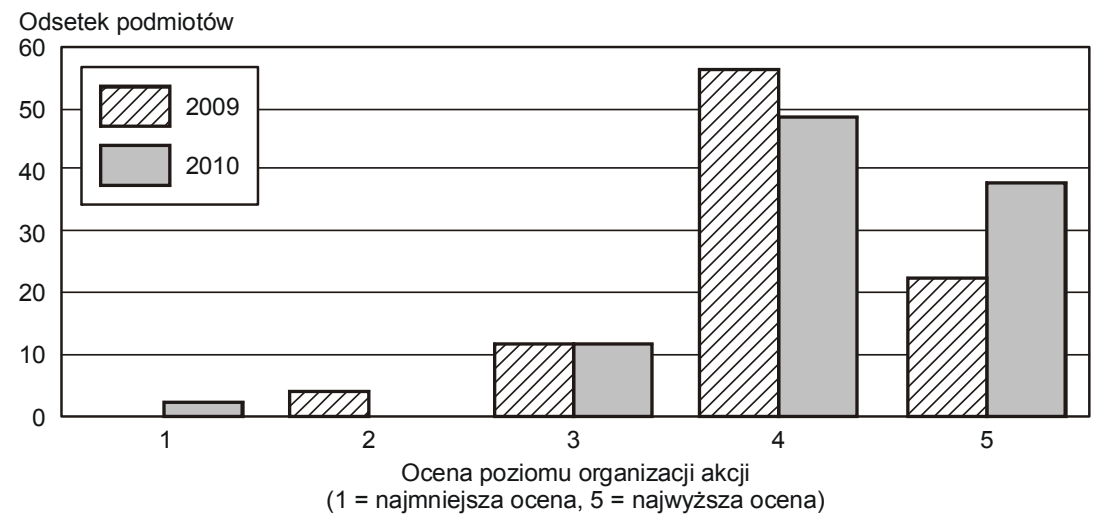

Rys. 1. Ocena poziomu organizacji akcji „Poznań za pół ceny” przez partnerów (2009-2010) Źródło: opracowanie własne

latach ich liczba przyrastała odpowiednio o 66 i 95\%. Analogicznie, liczba podmiotów rezygnujących $\mathrm{z}$ udziału spadała $\mathrm{w}$ tym samym tempie i zakresie, niemniej nie można obliczyć szczegółowego wskaźnika określającego ten proces ze względu na brak dokładnych danych. Według koordynatora akcji powodem rezygnacji był najczęściej brak zbieżności taktyki promocyjnego obniżania cen $z$ indywidualnymi strategiami marketingowymi, bierność i otwarta niechęć do wspólnych inicjatyw oraz brak wiary w skuteczność akcji, przy czym oddziaływanie ostatniego z tych czynników zostało $\mathrm{w}$ trzecim roku akcji znacznie zmniejszone. Wzrost liczby podmiotów partycypujących we wspólnej obniżce cen był zarówno rezultatem wysokiej ogólnej skuteczności marketingowej akcji (tab. 1), jak i indywidualnych ocen korzyści uzyskanych przez podmioty $\mathrm{w}$ niej uczestniczące. Należy jednak stwierdzić, że rozwój partnerstwa jest pochodną oceny bieżącego poziomu organizacji wspólnego projektu (rys. 1). W tym przypadku wyniki okazały się jednoznacznie pozytywne - największa liczba podmiotów (56\% w 2009 r. oraz $48 \%$ w 2010 r.) określiła go jako dobry. Widoczny jest wyraźny wzrost ocen najwyższych - od $22 \%$ do $38 \%$. Należy zaznaczyć, że te oceny stanowią pośrednio legitymizację PLOT jako koordynatora działań partnerskich. Najczęściej zgłaszanymi kwestiami były problemy z przekazywaniem materiałów promocyjnych wynikających ze zbyt późnego „zamknięcia” listy partnerów.

Podmioty, które wzięły udział w akcji wysoko oceniły proces współpracy, co jest najbardziej bezpośrednim miernikiem kondycji partnerskiej (rys. 2). Przewaga dobrych i bardzo dobrych ocen jest bardzo wyraźna - 78\% po drugiej edycji i $86 \%$ po trzeciej. Co więcej, tutaj także zauważalny jest 
trend rosnący w odniesieniu do ocen najwyższych - w roku 2009 stanowiły one 38\% wszystkich ocen, a w 2010 aż 64\%. Potwierdzeniem weryfikacji potencjału partnerskiego była struktura odpowiedzi na pytanie o stopień zainteresowania udziałem $\mathrm{w}$ kolejnych wspólnych inicjatywach podejmowanych w przyszłości w Poznaniu (rys. 3). Okazało się, że niemal 3/4 podmiotów biorących udział w akcji wykazała wysokie zainteresowanie, a jeśli dodać do tego oceny o jeden stopień niższe, okazało się, że aż 9 na 10 podmiotów jest jednoznacznie skłonna do dalszych działań.

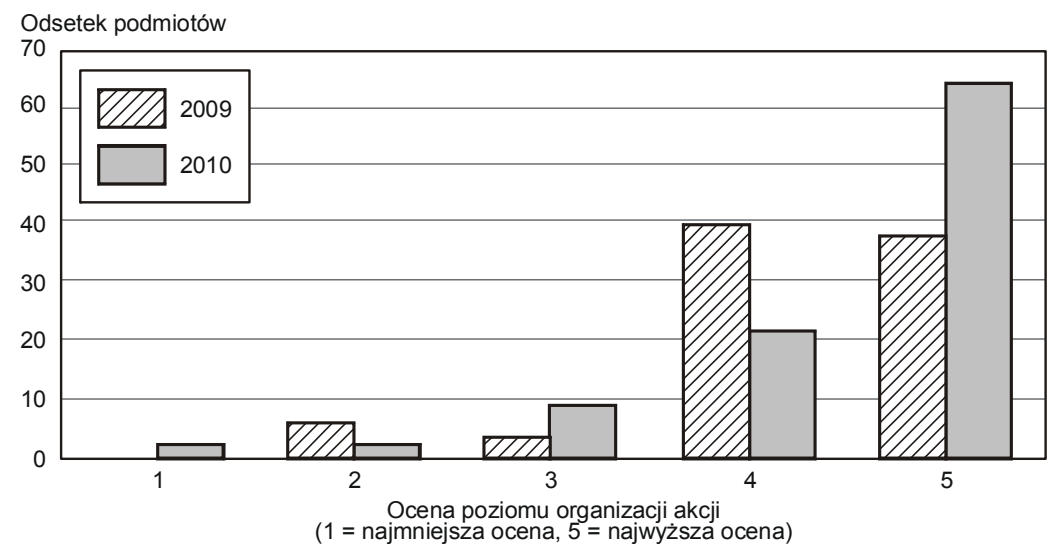

Rys. 2. Ocena współpracy w ramach organizacji „Poznań za pół ceny” przez partnerów (2009-2010) Źródło: opracowanie własne

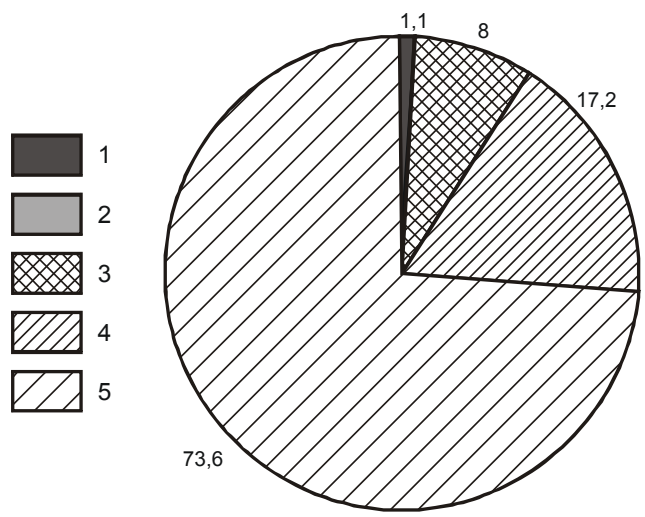

Rys. 3. Zainteresowanie partnerów udziałem we wspólnych inicjatywach marketingowych Objaśnienia: poziom zainteresowania: 1 - najniższy, 5 - najwyższy Źródło: opracowanie własne 


\section{Podsumowanie}

Zaprezentowane rezultaty badań ujawniły rosnący poziom współpracy $\mathrm{w}$ zakresie turystyki w Poznaniu oraz duży potencjał partnerski tkwiący w lokalnej gospodarce turystycznej. Można stwierdzić, że wspólne decyzje cenowe $\mathrm{w}$ formie promocji sprzedaży produktu turystycznego miasta pozytywnie zweryfikowały możliwości podjęcia bardziej zaawansowanych inicjatyw o strategicznym charakterze. Omówiony przypadek wspólnych obniżek cen wskazuje, że instrument ten może być skuteczny w testowaniu przez podmiot przywódczy potencjału partnerskiego istniejącego w miejscowości lub regionie turystycznym. Jego użyteczność tkwi w charakterystyce zachęt cenowych. Po pierwsze, warunkiem powodzenia $w$ tym wypadku jest aktywne uczestnictwo ( $\mathrm{w}$ formie działania, a nie tylko decyzji) wielu podmiotów - niemożliwe jest, aby równoczesne obniżenie cen wielu usług zostało zrealizowane przez jeden bądź kilka tylko podmiotów, zatem jest to jedno $\mathrm{z}$ niewielu narzędzi marketingowych, w którym orientacja partnerska jest tak silna. Po drugie, nakłady finansowe i organizacyjne potrzebne do przeprowadzenia obniżek cenowych są niskie w stosunku do innych instrumentów marketingowych, a gotowość i zdolność poszczególnych podmiotów do współpracy jest widoczna natychmiast. Po trzecie, wspólna promocja sprzedaży pozwala na szybkie zmierzenie stopnia zaangażowania każdego z partnerów zarówno $\mathrm{w}$ fazie koncepcyjnej i przygotowawczej, jak i podczas przeprowadzenia samej akcji marketingowej. Potencjalny sukces wykorzystania tego instrumentu stanowi solidną miarę zaangażowania i siły współdziałania partnerów. Z drugiej strony ewentualna porażka nie spowoduje poważnych problemów w kreowaniu pozytywnego wizerunku obszaru turystycznego, a także nie doprowadzi do upadku partnerstwa. Niezależnie od wyniku, wiedza wynikająca $\mathrm{z}$ weryfikacji siły partnerstwa jest nieporównywalnie większa.

\section{BIBLIOGRAFIA}

Ashworth G.J., Voogd H., 1994, Marketing and Place Promotion, [w:] Place Promotion: The Use of Publicity and Marketing to Sell Towns and Regions, J.R. Gold, S.V. Ward (eds.), John Wiley \& Sons, Chichester, s. 39-52.

BRAMwell B., LANE B., 2000, Collaboration and partnerships in tourism planning, [w:] Tourism Collaboration and Partnerships, B. Bramwell, B. Lane (eds.), Channel View Publications, Clevedon, s. 1-19. 
BuHALIS D., 2000, Marketing the competitive destination of the future, „Tourism Management”, No. 21(1), s. 97-116.

CAFFYN A., 2000, Is there a tourism partnership life cycle?, [w:] Tourism Collaboration and Partnerships, B. Bramwell, B. Lane (eds.), Channel View Publications, Clevedon, s. 200-229.

FloreK M., 2007, Podstawy marketingu terytorialnego, AE w Poznaniu, Poznań.

Fyall A., GARROD B., 2005, Tourism Marketing: A Collaborative Approach, Channel View Publications, Clevedon.

IMAS, 2006, Z czym Poznań się kojarzy? IMAS. International Polska, Wrocław.

Instytut Turystyki, 2010, Sektor turystyki - definicje, analizy, dane liczbowe i prognozy, http://www. intur.com.pl/statystyka.htm; $18.09 .2010 \mathrm{r}$.

KolB B.M., 2006, Tourism Marketing for Cities and Towns: Using Branding and Events to Attract Tourists, Butterworth-Heinemann, Oxford.

Kotler P., Haider D.H., ReIN I., 1993, Marketing Places: Attracting Investment, Industry and Tourism to Cities, States and Nations, The Free Press, New York.

KRUCZEK Z., ZMYŚLONY P., 2010, Regiony turystyczne, Proksenia, Kraków.

MinTEL, 2005, Destination Marketing, "Travel \& Tourism Analyst”, No. 5, April.

MurPHY P.E., MuRPHY A.E., 2004, Strategic Management for Tourism Communities: Bridging the Gaps, Channel View Publications, Clevedon.

OlsZEWSKI M.., ZMYŚLONY P., 2008, Ocena skuteczności akcji „Poznań za pót ceny”. Raport z badań przeprowadzonych na zlecenie PLOT (materiał niepublikowany), Poznań.

OLSZEWSKI M.., ZMYŚLONY P., 2009, Ocena skuteczności akcji "Poznań za pót ceny” 2009. Raport $z$ badań przeprowadzonych na zlecenie PLOT (materiał niepublikowany), Poznań.

PikKemaAt B., 2004, The measurement of destination image: the case of Austria, "The Poznan University of Economics Review", No. 4(1), s. 87-102.

Ritchie J.R.B., Crouch G.I., 2003, The Competitive Destination: A Sustainable Tourism Perspective, CABI Publishing, Wallingford.

SAMUELSON P.A., NORDHAUS W.D., 1995, Economics, McGraw-Hill, New York.

SOCHER K., 2006, The contribution of the State to more efficient and effective marketing, [w:] Marketing Efficiency in Tourism: Coping with Volatile Demand, P. Keller, T. Bieger (eds.), Erich Schmidt Verlag, Berlin, s. 193-202.

SZMATUŁA P., ZMYŚLONY P., 2010, Ocena skuteczności akcji „Poznań za pót ceny” 2010. Raport z badań przeprowadzonych na zlecenie PLOT, materiał niepublikowany, Poznań.

WOOD D.J., GRAY B., 1991, Toward a comprehensive theory of collaboration, "Journal of Applied Behavioral Science", No. 27(2), s. 139-162. 